\title{
Credit Risk, Market Power and Exchange Rate as Determinants of Banks Performance in Nigeria.
}

\author{
Shuaib Ndagi Sayedi* \\ Department of Business Administration Faculty of Management and Social Sciences Ibrahim Badamasi \\ Babangida University P.M.B 11, Lapai-Niger State, Nigeria
}

\begin{abstract}
Performance of banks is mostly measured by profitability (ROA \&ROE). Profitability is determined by bank-specific and industrial/macroeconomic variables. The former is controllable variables and the latter is uncontrollable variables. The objectives of the study were to examine the effects credit risk, market power, exchange rate on the profitability of banks in Nigeria. The population of study is fifteen (15) quoted Deposit Money Banks in the Nigerian Stock Exchange (NSE). Data are collected from secondary source of the quoted banks' annual reports (2006 - 2011). Linear regression is used as tool of the analysis of the study. The empirical results of model one show that market power has significant positive effect on profitability (ROA) while exchange rate has insignificant positive effect on profitability (ROA). Besides, credit risk has insignificant negative effect on profitability. The model two results also reveal that market power has significant positive effect on profitability (ROE). Exchange rate has significant negative effect on profitability (ROE) while credit risk has insignificant negative effect on profitability. The study recommends that banks managements should continue to: increase and maintain their market share known as market power. The reason is that, the significant rise in market power has positive relationship with the profitability of banks. Secondly, adequately anticipate exchange rates fluctuations they transact on, despite exchange rate has significant negative effect on profitability of banks measured by ROE. This is because stable exchange rates add value to the profitability of banks in Nigeria. Lastly, ensure that they continue to maintain low level of credit risk in order to increase the profitability. This is because the insignificant decline in credit risk has negative effect on the profitability of banks.

Key words: Credit Risk; Market power; Exchange Rate, ROA; ROE.
\end{abstract}

\section{Introduction}

Banks are extraordinary financial intermediary that mobilizes money between depositors and borrowers participating in an economy. How well they perform this intermediary function has direct linkage with banks performance and economic health of a nation. Performance which is the profitability of banks has effects on growth and development of an economy. Because of this reason, banking regulatory authorities in many nations worldwide came up with various banking reforms agenda with specific emphasis on variables determining banks profitability.

Banking industries had experienced major reforms worldwide for over three decades now in their operating environments. United Kingdom responded to its banking crisis which spanned between 1973 and 1976 through the consolidation of banking industry and conversion of building societies into banks; United States of America responded to its banking crisis which spanned between 1982 and 1990 by consolidation through mergers and acquisitions; Spain responded to its banking crisis by establishment of the bank hospital known as the Guarantee fund; and Malaysia responded to its banking crisis by major banking consolidation exercises in 1999 with gradual removal of the barrier to the entry of foreign banks (Karwai, ${ }^{[1]} 2006$ and Yuqi $,{ }^{[2]}, 2008$ ).

Nigerian banking industry is not exempted from the reforms agenda. This is because, since the establishment of the Central Bank of Nigeria (CBN) in 1958 which commenced its banking business in 1959, the Nigeria banking industry had been affected by major economic and banking reforms. These reforms include the financial system reforms (1986 - 1993), re-introduction of banking sector regulation (1993-1998), universal banking (2001-2004) and the banking reform of 2004 to date (Sanusi, ${ }^{[3]} 2010$ and Egwurube ${ }^{[4]}, 2012$ ).

The Nigerian banking reform of 2004 had listed thirteen items to transform the industry. Banking capitalization, mergers and acquisitions are among items of the reform agenda in order to boost capital adequacy and profitability of banks operating in Nigeria environment (Soludo ${ }^{[5]}$ 2004). The profitability of banks may be determined by Return on Assets (ROA), Return on Equity (ROE), Return on Capital Employed (ROCE) and Net Interest Margin (NIM). Capital adequacy is not the only determinant that may improve the profitability of banks, other determinants such as credit risk, market power and exchange rate are equally important. These determinants are known as bank specific and industrial/macroeconomic variables. 
The following research questions are highlighted for this study:

i. To what extent does credit risk have effect on the profitability of banks in Nigeria?

ii. To what extend does market power cause the profitability of banks in Nigeria?

iii. To what extend does exchange rate affect the profitability of banks in Nigeria?

The main objective of this study is to determine the effects of bank specific and industrial/macroeconomic variables on the performance of banks in Nigeria. To be specific, the study intends to determine the effect of:

i. $\quad$ Credit risk on the profitability of banks in Nigeria.

ii. Market power on the profitability of banks in Nigeria.

iii. Exchange rate on the profitability of banks in Nigeria.

The hypotheses are stated in null form for testing below:

$\mathrm{HO}_{1}$ : Credit risk has no significant effect on the profitability of banks in Nigeria.

$\mathrm{HO}_{2}$ : Market power has no significant effect on the profitability of banks in Nigeria.

$\mathrm{HO}_{3}$ : Exchange rate has no significant effect on the profitability of banks in Nigeria.

\subsection{Credit Risk}

Credit risk is a risk that customers default or fail to comply with debt servicing. Credit risk may be defined as provision against defaulted loans and advances that are risky. The riskiness is because it affects banks profitability. Sufian ${ }^{[6]}$ (2011) sees credit risk as how the bank is provision in a year relative to total loan. But, Srairi $^{[7]}(2009)$ perceives credit risk as the percentage of net loan to total assets. Ramlall ${ }^{[8]}$ (2009) observes credit risk as the provision for bad and doubtful debts to total loans and advances. Flamini, McDonald and Schumacher ${ }^{[\rho]}$ (2009) view credit risk as the proportion of total loans to total assets. Thus, credit risk is critical to bank managements and care must be taken so that it does not affect banks profitability.

\subsection{Market Power}

Market power known as market share is how a bank is leading an industry. Market power is defined as how much profit a bank earns in relation to other banks operating in an industry. It is also profit of individual bank over profits of banks operating in an industry. Flammini et al. ${ }^{[9]}$ (2009) view market power as individual bank's loan over banking industry loan to domestic private sector.

\subsection{Exchange Rate}

Exchange rate is necessary because of the differences in value of currencies between nations. Exchange rate may be defined as the value of one nation's currency in relation to the value of other nations' currencies. It is also defined as how much a Naira exchanges for one US Dollar. Jhingan ${ }^{[10]}$ (2001) observes exchange rate as the price one unit of the foreign currency in terms of the domestic currencies. The exchange rate between the Dollar and Naira refers to the number of Dollars required to purchase a Naira $(\$ 165=\$ 1)$. Solomon ${ }^{[11]}(2007)$ views exchange rate as the rate at which one currency exchanges for another. Pandey ${ }^{[12]}$ (2010) sees foreign exchange rate as the price of one currency quoted in terms of another currency. Exchange rate system establishes a structural frame work for conducting foreign exchange transactions that affect banks profitability. Samoye $^{[13]}$ (2008) identifies that the increase in average value of Naira/Dollar from \$142.52 (Year 2005) to $\$ 137.10$ (Year 2006) initiated the decline in banks profitability (ROA) in Nigeria from 3.01 percent to 2.07 percent for the same years respectively.

The above schematic model is designed by the researcher and used to determine the profitability of banks in Nigeria. Return on Assets is a measure of profitability which is determined by bank-specific and industrial/macroeconomic factors. The bank-specific factor is bank size. The industrial factor is market power while macroeconomic factor is exchange rate. These variables are used to determine the profitability of banks in Nigeria because the previous studies suggested that there are strong determinants in other nations. Besides, these variables are a mixture of bank specific, industrial specific and macroeconomics which are controllable and uncontrollable factors.

\section{Related Empirical Literatures on Banks Performance}

Proxies determining banks performance which is the profitability are many. Though, these proxies vary from one country to another in determining banks profitability because of the differences in the economic system. Saidu and $\operatorname{Tumin}^{[14]}$ (2011) investigated the performance and financial ratios on samples of four Malaysian and nine Chinese commercial banks from 2001 to 2007. The research made use of panel data and the regression results show that credit, capital and operating ratios have influence on the performance of banks in China which is not true for Malaysia. Liquidity and size of the banks do not influence the performance of the banks in both countries. Gul, Irshad and Zaman ${ }^{[15]}$ (2011) studied the factors affecting samples of 15 
commercial banks profitability in Pakistan from 2005 to 2009. The investigation utilized a regression model, panel data estimation and Pooled Ordinary Least Square (POLS) method of computation with the aid of an econometric package. The econometric result indicates that bank size and capital adequacy have significant negative influences on profitability while capital and GDP have significant positive influences on profitability measured by Return on Equity (ROE). Ali, Akhtar and Ahmed ${ }^{[16]}$ (2011) examined the bank specific and macroeconomic indicators of 22 public and private sector commercial banks profitability in Pakistan from 2006 to 2009. The research made use of multiple regression models and panel data estimation with the help of SPSS statistical package. The findings show that bank size, operating efficiency, asset management and GDP have positive effect on banks' profitability. However, capital and credit risk have negative effect on banks profitability in Pakistan. The study recommended that the results will be of value to both academics and policy makers. Sufian ${ }^{[6]}$ (2011) also investigated the profitability of 251 Korean banks from 1992 to 2003 . The study used panel data, multiple regression models and econometric statistical package. The regression results indicate that liquidity and inflation have significant positive effects on profitability. Bank size and capital have insignificant positive effects on profitability while credit risk and GDP have insignificant negative effects on profitability measured by Return on Equity (ROE).

Srairi ${ }^{[7]}(2009)$ examined factors influencing the profitability of Conventional and Islamic commercial banks in Gulf Cooperation Council (GCC) countries of Bahrain, Kuwait, Oman, Qatar, Saudi Arabia and United Arab Emirates (UME). The study was conducted on samples of 66 commercial banks (48 conventional and 18 Islamic) for period ranging from 1999 to 2006. The study utilized regression model and panel data inputted in SPSS package. The empirical results indicate that liquidity and credit risk have a significant positive impact on Conventional banks' profitability. But, liquidity and credit risk have insignificant negative impact on Islamic banks' profitability. Moreover, Capital adequacy, bank concentration, money supply and banking sector GDP have significant positive influence on both Conventional and Islamic commercial banks' profitability. Inflation has insignificant influence on the profitability of all banks operating in GCC countries. King Fahd University ${ }^{[17]}$ (2010) also studied profitability of 44 Islamic banks operating in GCC region from 2000 to 2009. The regression results show liquidity has insignificant positive impact on banks' profitability but inflation and GDP have significant positive impact on Islamic banks profitability in GCC countries. Khrawish ${ }_{1}$, Siam and Khrawish ${ }_{2}^{[18]}$ (2011) investigated the determinants on samples of three Jordan Islamic banks profitability from 2005 and 2009. The multiple linear regression results show that bank size and exchange rate have significant positive relationships with profitability. But, capital, credit risk, GDP and inflation have significant negative relationships with profitability measured by ROE.

Yuqi $^{[2]}(2008)$ examined the determinants of 123 United Kingdom (UK) banks profitability and its implication on risk management from 1999 to 2006. The study utilized multiple regression models and panel data estimation inputted in STATA econometric package. The econometric results indicate capital adequacy has significant positive impacts on profitability but inflation has insignificant positive impact on profitability. Liquidity and credit risk have significant negative impacts on profitability though; GDP and interest rate have insignificant negative impacts on the profitability of banks in UK. Coffinet, Lin and Martins ${ }^{[19]}$ (2010) studied stress in testing banks profitability in France from 1993 to 2008. The study utilized multivariate regression model and dynamic panel estimation using econometric statistical package. The result shows GDP, inflation, non-interest income and capital have positive effect on banks' profitability. Though, banks size and credit risk have negative effect on banks' profitability in France. Antonina ${ }^{[20]}$ (2011) investigated the determinant on samples of largest 10 banks (Domestic and foreign ownership) profitability in Ukraine from 2005 to 2009. The study used panel data estimation with the aid of STATA statistical package. The econometric results reveal that capital and bank size have significant positive effects on bank profitability but exchange rate has insignificant positive effect on profitability. Credit risk, inflation and foreign ownership of banks have significant negative effects on banks profitability while administrative expenses, liquidity and GDP have insignificant negative effects on the profitability of banks in Ukraine.

Tregenna ${ }^{[21]}(2009)$ investigated fat years of the structure and profitability of USA bank sector in the pre-crisis period from 1994 to 2005 . The investigation used linear regression model, panel data estimation technique and Generalized Method of Moment (GMM) technique with the aid of econometric package. The regression result indicates that bank concentration, market power and bank size increase banks' profitability. However, operational efficiency is not a strong determinant of banks' profitability in USA. Graham and Bordeleau $^{[22]}$ (2010) also study impact of liquidity on 55 sampled USA and 10 Canadian banks from 1997 to 2009. The regression result shows profitability of some banks that hold liquid asset improved. However, there was a point at holding further liquid assets diminish the banks' profitability.

Flamini et al. ${ }^{[9]}$ (2009) studied the determinants of 389 commercial banks profitability in 41 SubSaharan Africa (SSA) countries from 1989 to 2006. The investigation utilized linear regression model, unbalanced panel data and Granger causality test between the data of dependent and independent variables. The results show that apart from credit risk, higher return on assets (profits) are associated with large bank size, 
activity diversification, and private ownership. Furthermore, banks' profits are affected by macroeconomic variables or determinants such as inflation. The study supported macroeconomic policies that promote low inflation and stable output growth which boost credit expansion. Buyinza ${ }^{[23]}$ (2010) was on samples of 23 commercial banks profitability in Sub Sahara Africa countries from 1999 to 2006. The study utilized panel data and the regression results reveal that capital, efficient expenses management, bank size, credit risk, diversified earning ability of the banks, per capital GDP, growth rate and inflation have significant and positive impact on banks' profitability.

In Nigeria, $\mathrm{Sabo}^{[24]}$ (2007) investigated the determinants on samples of 10 commercial banks profitability from 1996 to 2005 . The study utilized panel data of primary source and descriptive statistic for analysis. The investigation found that the volume of operations more than any other factor determined the operating profits. Moreover, market capitalization, peer group ranking and combination of other important factors such as macroeconomics environment determined commercial banks' profitability in Nigeria. The investigation calls for more commitment to training and model development based on the internal peculiarities of banks on study. However, the study was conducted using primary data prior to 2004 banking reform on samples of 10 commercial banks in Nigeria. Ani, Ugwunta, Ezeudu and Ugwuanyi ${ }^{[25]}$ (2012) studied internal determinants on samples of 15 bank profitability from 2001 to 2010 in Nigeria. The regression result shows that bank size has insignificant negative relationship with profitability and capital has significant negative relationship with profitability. Besides, bank composition has significant positive relationship with profitability in Nigeria. This study used data before and after bank recapitalization policy of 2004. After recapitalization policy, banks assets were more than double and it is on just to include data before the year 2005 in determining banks profitability in Nigeria. Bosede, Olusegun and Olubukunola ${ }^{[26]}$ (2013) examined Return on Investment (ROI) of 24 DMBs from 1977 to 2010 in Nigeria. The econometric model and Eviews software results indicate that returns and profitability of commercial banks are significantly affected by macroeconomic variables (inflation, output growth, lending rate) and other bank characteristic factors such liquidity. Nevertheless, the study utilized pre and post consolidation data ranging from 1977 to 2010, and all sampled banks are not quoted in NSE. John and $\mathrm{Oke}^{[27]}(2013)$ investigated capital adequacy before and after banks recapitalization policy of 2004 in Nigeria. The study sampled 6 banks covering the period of 2003 to 2007. The ordinary least squares (OLS) estimation technique result indicates that capital adequacy influences bank performance (EPS and PAT). The study recommends that CBN should not rely solely on the capitalization of banks as a determinant of bank performance but also should concentrate on efficient and effective bank supervision and risk management. But, the study used pre and post consolidation data ranging from 2003 to 2007, and data of defunct banks (Intercontinental Bank and Oceanic bank) in Nigeria. In addition, bank industrial specific characteristics and macroeconomic factors are not used as variables of the study.

Similarly, Aremu, Ekpo, and Mustapha ${ }^{[28]}(2013)$ studied determinants of a bank profitability in a developing economy from 1980 to 2010 in Nigeria. The results of the econometric model indicate that liquidity, credit risk and capital adequacy are significant drivers of bank profitability. But bank size and cost efficiency are insignificant factors that determine banks profitability. On macroeconomics factors, money supply growth rate significantly determine bank profitability while GDP and inflation insignificantly determine bank profitability in Nigeria. Though, the study used pre and post consolidation data ranging from 1980 to 2010, and only First Bank was sampled for the study. Soyemi at al. ${ }^{[29]}$ (2013) investigated the determinants on samples of 10 DMBs profitability (ROA and NIM) from 2006 to 2010 in Nigeria. The linear regression result indicate that bank size and capital adequacy have significant negative relationship with banks profitability while management expenses and deposits have insignificant positive relationship with banks profitability. In addition, external determinants such as GDP growth rate, inflation, interest rate and market capitalization have insignificant positive relationship with banks profitability in Nigeria. But, the study sampled only 10 banks out of 15 quoted DMBs in Nigeria. Aminu. ${ }^{[30]}$ (2013) examined determinants on samples of 7 banks profitability from 2005 to 2011 in Nigeria. The regression result reveals that only management efficiency is the driving force determining bank profitability (ROA and ROE). Liquidity has insignificant positive impact on profitability while capital adequacy and asset quality have insignificant negative impact on profitability. Macroeconomic factor such as GDP growth rate has significant negative impact on profitability but inflation has insignificant negative impact on profitability of banks in Nigeria. However, the study sampled only 7 banks out of 15 quoted DMBs in Nigeria.

These are the limitations discovered in the earlier researches in determining the profitability of banks in Nigeria. These limitations are gaps in the field of academic discussion. Therefore, this study intends to fill the existing gaps in order to advance the frontiers of knowledge. Further studies should include more of industrial specific variables like bank concentration, bank regulation, market capitalization and bank ownership in combination with other variables that determine profitability of banks. This is because industrial characteristics are common to banks operating in an economy of a nation. 


\section{Research Methodology}

This research study adopts ex post facto type of research design in which data are collected from secondary source (Annual reports and statement of accounts) only. The data consist of variables of quoted Deposit Money Banks (DMBs) and Central Bank of Nigeria (CBN). The independent variables are credit risk, market power and exchange rate that are controllable and uncontrollable factors while dependent variable is performance which is the profitability (ROA and ROE) of quoted banks. Precisely, the controllable factor is credit risk which is bank specific factor. But, the uncontrollable factors are market power and interest rate which are industrial/macroeconomic factors. Linear regression models and Pearson Product Moment Correlation coefficients are used in the analysis of data with the help of Statistical Package for Social Sciences (SPSS) version 16.

The population of the study is 15 quoted Deposit Money Banks (DMBs) in Nigeria Stock exchange (see appendix I). This study only uses the population of the quoted banks because their activities are public and data relating to variables under study are directly or indirectly stated in the banks' annual reports.

The census population of fifteen (15) quoted DMBs is utilized. This is because the population is small and data relating to variables under study are available in annual reports of the quoted banks and CBN bulletin. So, no sample size and sampling techniques were adopted for this study.

To test the relationship/effect of bank specific and industrial/macroeconomics determinants on the profitability of banks described earlier, this study adopts linear regression models as follows:

Model 1:

Model 2:

$$
\text { Profitability }(\text { ROA })=\alpha+\mathrm{B}_{1} \text { CRisk }+\mathrm{B}_{2} \mathrm{MKTpower}+\mathrm{B}_{3} \text { ExRate }+\mathrm{e} \ldots \ldots \ldots \ldots \ldots \ldots \ldots \ldots . \mathrm{i}
$$

$$
\text { Profitability }(\mathrm{ROE})=\alpha+\mathrm{B}_{1} \text { CRisk }+\mathrm{B}_{2} \text { MKTpower }+\mathrm{B}_{3} \text { ExRate }+\mathrm{e} \ldots \ldots \ldots \ldots \ldots \ldots \ldots . . . \mathrm{ii}
$$

Where:

$\begin{array}{lll}\text { ROA } & = & \text { Return on Assets } \\ \text { ROE } & = & \text { Return on Equity } \\ \alpha & = & \text { Constant or intercept } \\ \mathrm{B}_{1} \ldots . \mathrm{B}_{3}= & & \text { Régression coefficients } \\ \text { CRisk }= & & \text { Credit Risk } \\ \text { MKTpower } & = & \text { Market Power. } \\ \text { GDP } & = & \text { Gross Domestic Product } \\ \mathrm{e} & = & \text { Error term. }\end{array}$

Return on Assets (ROA) and Return on Equity (ROE) are used as measurements of banking profitability because both represent the Return on Investment (ROI). ROA indicates how efficiency management uses available resources (Total assets) to generate income. While, ROE indicates how efficiency management uses available owners' resources (Shareholders' equity) to generate income. Measurement using ROE coincides with one of the objectives of establishing business enterprises that is to maximize returns on the shareholders' funds (Pandey ${ }^{[12]}, 2010$ ).

In this study, ROA is measured by loss/profit after tax or net income over total assets .But, ROE is measured by loss/profit after tax or net income over total shareholders' equity. This is because many previous studies such as Ramllah ${ }^{[8]}$ (2009), Flamini et al. ${ }^{[9]}$ (2009), Gul et al. ${ }^{[15]}$ (2011) and Khrawish et al. ${ }^{[18]}$ (2011) use net income over total assets to measure ROA. But, few studies such as Srairi ${ }^{[7]}$ (2009) and $\operatorname{Sufian}^{[6]}(2011)$ use net income over average total assets to measure ROA. This also goes the same with the measurement of ROE. In addition, newly established banks that are preparing their financial statements for the first time in their second year in business may not have previous year(s) financial statements to measure banking profitability using average total assets or average total shareholders' equity. Moreover, there is no significant difference between using net income over total assets and net income over average total assets in measuring ROA (Shim \& Siegel ${ }^{[32]}, 2007$ and Pandey ${ }^{[12]}, 2010$ ).

The independent variables such as credit risk, market power and exchange rate that have effects on banks profitability are measured as: Credit risk is net loan over total assets. Market power is per annual Individual bank's net income over banking industry net income while exchange rate is average bureau de change exchange rates $(\# / \$)$ extracted from $\mathrm{CBN}$ annual reports.

Furthermore, Pearson Product Moment correction coefficient $(-1 \leq \mathrm{r} \leq 1)$ is utilized to test the strength/significance of relationships while the regression is used to test the effect/significance of relationships among the study variables. The significance level ranges from $0.000-0.005$ (1\% level of significance), 0.006 -0.010 (5\% level of significance) and $0.011-0.099$ (10\% level of significance) which one percent level of significance is considered stronger than others (Khrawish et al. ${ }^{[18]}, 2011$ ). 
In order to test the hypotheses, we accept the null hypotheses if the results of this study are the same with the stated hypotheses $\left(\mathrm{HO}_{1}, \mathrm{HO}_{2}\right.$ and $\left.\mathrm{HO}_{3}\right)$ at one percent, five percent and ten percent level of significance; otherwise we reject the null hypotheses. This will enable the researcher to test the effects of both controllable and uncontrollable factors on the profitability of banks in Nigeria.

\section{Data Presentation and Analysis}

This section presents data of variables and summary results of the study in tables. These tables include descriptive statistics, correlation coefficient matrixes and regression results. The data analyses are done with the aid of SPSS using regression models to test the hypotheses.

TABLE 1.1 Descriptive Statistics

\begin{tabular}{|c|c|c|c|c|c|c|c|}
\hline Variable & $\mathrm{N}$ & Range & Minimum & Maximum & Mean & Median & Std. Deviation \\
\hline Return on Assets & 90 & 58.76 & -44.80 & 13.96 & .7696 & 1.685 & 5.73202 \\
\hline Return on Equity & 90 & 263.87 & -86.84 & 177.03 & 8.9913 & 10.0300 & 26.99414 \\
\hline Credit Risk & 90 & 48.44 & 12.60 & 61.04 & 36.6273 & 36.155 & 10.97277 \\
\hline Market Power & 90 & 455.07 & -304.67 & 150.40 & 6.6667 & 5.76 & 52.24527 \\
\hline Exchange Rate & 90 & 40.83 & 120.81 & 161.64 & 143.2217 & 145.08 & 15.81829 \\
\hline Valid N (listwise) & 90 & & & & & & \\
\hline
\end{tabular}

Source: Author Computation using SPSS, 2013.

The TABLE 1.1 shows descriptive statistics of the variables used to measure 15 quoted banks profitability for six years. Return on Asset (ROA) is relatively low with mean, median and standard deviation of 0.7696, 1.685 and 5.73202 percent respectively. The minimum value of ROA is -44.8 percent and maximum value is 13.96 percent. This reveals that there is variation of 58.76 percent in the data set of ROA among the quoted banks. The implication is that the profitability of banks is not normally distributed throughout the period of study which affects investors of some banks negatively. This is because ROA is a measure of Return on Investment (ROI) and it indicates how efficient managements use banks' total assets.

Return on Equity (ROE) is also low with mean, median and standard deviation of 8.9913, 10.0300 and 26.99414 percent respectively. The minimum value of ROE is -86.84 percent and maximum value is 177.03 percent. This means that there is variation of 263.87 percent in the data set of ROE among the banks. The implication is that the profitability of banks is highly skewed to one size affecting shareholders' equity of some banks.

In addition, credit risk is slightly high with mean, median and standard deviation of $36.6273,36.155$ and 10.97277 percent respectively. The minimum value of credit risk data set is 12.60 percent and the maximum value is 61.04 percent. This means that there is variation of 48.44 percent in the data set of sampled banks' credit risk. It implies that banks made adequate provision for defaulted risk.

Market power is also high with mean, median and standard deviation of 6.67, 5.76 and 52.25 percent respectively. The minimum value of data set for market power is -304.67 percent and the maximum value is 150.40 percent. This shows that market power has variation of 455.06 percent in the data set. It implies that market power known as market share of some banks are high. This market share enables a bank to be a leader in terms of monopolizing the profit of an industry while others become followers and niches.

Lastly, exchange rate is low with mean, median and standard deviation 143.2217, 145.08 and 15.81829 Naira/US Dollar respectively. The minimum value of exchange rate is 120.81 and maximum value is 161.64 Naira/ US Dollar. The variation in exchange rate is 40.83 Naira/ US Dollar because of the relative stability in exchange rate during the six years post banking reform period in Nigeria.

\subsection{Correlation Matrixes}

The matrixes are two, providing information on the degree of relationship between dependent and independents variables using one (1) tail test of Pearson Product Moment correlation coefficient (see TABLE $2.1 \& 2.2$ below). 
TABLE 2.1 Correlation Matrix between the Study Variables and Profitability (ROA) of Banks

\begin{tabular}{|ll|r|r|r|r|}
\hline \multicolumn{1}{|c|}{ Variables } & Return on Assets & Credit Risk & Market Power & Exchange Rate \\
\hline Return on Assets & Pearson Correlation & 1 & -0.116 & \\
& Sig. (2-tailed) & & 0.278 & \\
& $\mathrm{~N}$ & 90 & 90 & \\
\hline Credit Risk & Pearson Correlation & -0.116 & & \\
& Sig. (2-tailed) & 0.278 & & \\
& $\mathrm{~N}$ & 90 & 90 & \\
\hline Market Power & Sig. (2-tailed) & $0.269 * *$ & 0.074 & \\
& $\mathrm{~N}$ & 0.010 & 0.486 & \\
& Pearson Correlation & 90 & 90 & 1 \\
\hline Sig. (2-tailed) & $\mathrm{N}$ & 0.015 & $0.503 * * *$ & 90 \\
\hline
\end{tabular}

*. Correlation is significant at the 0.05 level (2-tailed).

**. Correlation is significant at the 0.01 level (2-tailed).

***. Correlation is significant at the 0.01 level (2-tailed).

Significance Level: One percent (***), Five percent $(* *)$, Ten percent $(*)$

Source: Author Computation using SPSS, 2013.

TABLE 2.1 indicates correlation matrix between bank size, market power, exchange rate and profitability (ROA) of quoted banks in Nigeria. Market power has the highest significant positive correlation coefficient value of 0.269 . Thus, market power has relatively weak positive relationship with profitability. This means market power will significantly rise with banks profitability which is significant at $10 \%$ level.

Exchange rate has insignificant positive correlation coefficient value of 0.015 . Exchange rate also has weak positive relationship with profitability. This reveals that exchange rate will insignificantly rise with banks profitability.

Though, credit risk has insignificant negative correlation coefficient value of -0.053 . Thus, credit risk has weak negative relationship with profitability. This discloses that credit risk will insignificantly decline with banks profitability.

From the above analysis, market power has significant positive relationship with profitability. Exchange rate has insignificant positive relationship with profitability while credit risk has insignificant negative relationship with banks profitability in Nigeria. There is no problems multicollinearity since none of the correlation coefficients are more than $0.75\left(\operatorname{Sufian}^{[6]}, 2011\right)$.

TABLE 2.2 Correlation Matrix between the Study Variables and Profitability (ROE) of Banks

\begin{tabular}{|ll|r|r|r|r|}
\hline & Variable & Return on Equity & Credit Risk & Market Power & Exchange Rate \\
\hline Return on Equity & Pearson Correlation & 1 & $-0.208 *$ & & \\
& Sig. (2-tailed) & & 0.049 & & \\
& $\mathrm{~N}$ & 90 & 90 & & \\
\hline Credit Risk & Pearson Correlation & $-0.208 *$ & 1 & & \\
& Sig. (2-tailed) & 0.049 & & & \\
& $\mathrm{~N}$ & 90 & 90 & & \\
\hline Market Power & Pearson Correlation & $0.180 *$ & 0.074 & & \\
& Sig. (2-tailed) & 0.089 & .486 & & \\
& $\mathrm{~N}$ & 90 & 90 & & \\
& Pearson Correlation & $-0.267 *$ & $0.503 * * *$ & 90 & \\
\hline Exchange Rate & Sig. (2-tailed) & 0.011 & 0.000 & 0.000 & \\
& $\mathrm{~N}$ & 90 & 90 & 1.000 & \\
& & & 90 & \\
\hline
\end{tabular}

*. Correlation is significant at the 0.10 level (2-tailed).

**. Correlation is significant at the 0.05 level (2-tailed).

***. Correlation is significant at the 0.01 level (2-tailed).

Significance Level: One percent (***), Five percent (**), Ten percent $(*)$ 
Source: Author Computation using SPSS, 2013.

TABLE 2.2 indicates correlation matrix between credit risk, market power, exchange rate and profitability (ROE) of banks in Nigeria. Market power has the highest significant positive correlation coefficient value of 0.180 . Therefore, market power has relatively weak positive relationship with profitability. This means market power will significantly rise with banks profitability which is significant at $10 \%$ level.

But, credit risk has significant negative correlation coefficient value of -0.208 . Therefore, credit risk has weak negative relationship with profitability. This discloses that credit risk will significantly decline with banks profitability which is significant at $10 \%$ level.

In addition, exchange rate has significant negative correlation coefficient value of -0.267 . It also has weak negative relationship with profitability. This reveals that exchange rate will significantly decline with banks profitability which is significant at $10 \%$ level.

The above analysis indicates that market power has significant positive relationship with profitability while credit risk and exchange rate have significant negative relationships with banks profitability in Nigeria. There is no problems multicollinearity since none of the correlation coefficients are more than 0.75 (Sufian ${ }^{[6]}, 2011$ ).

\subsection{Results of the Models}

The models provide information on effect, relationship and significance that exist between dependent and independent variables (explanatory variables) as shown in table 3.1 and 3.2 below:

TABLE 3.1: Summary of Regression Result (Model one)

\begin{tabular}{|c|c|c|c|c|}
\hline \multirow[b]{2}{*}{ Model 1} & Coefficients & \multirow[b]{2}{*}{ Standard Error } & \multirow[b]{2}{*}{$\mathbf{t}$} & \multirow[b]{2}{*}{ Significance Level } \\
\hline & $\beta$ & & & \\
\hline Constant $(\alpha)$ & -1.545 & 5.407 & -0.286 & 0.776 \\
\hline Credit Risk & -0.101 & 0.062 & -1.624 & 0.108 \\
\hline Market Power & $0.031^{* * *}$ & 0.011 & 2.7560 .943 & 0.007 \\
\hline Exchange Rate & 0.040 & 0.043 & & 0.348 \\
\hline & 0.316 & & & \\
\hline & 0.100 & & & \\
\hline Adjusted $\mathrm{R}^{2}$ & 0.069 & & & \\
\hline F Statistics & $3.184 *$ & & $\rightarrow$ & \\
\hline Significance of $\mathrm{F}$ & $\rightarrow$ & $\rightarrow$ & & 0.028 \\
\hline Durbin Watson & 1.893 & & & \\
\hline
\end{tabular}

Dependent variable: Return on Asset (Profitability).

Significance Level: One percent $(* * *)$, Five percent $(* *)$, Ten percent $(*)$

Source: Author Computation using SPSS, 2013.

The TABLE 3.1 indicates the values of estimated linear regression coefficients of credit risk, market power and exchange rate. Market power has significant positive coefficient $\beta$ value of 0.031 with standard error of $0.011, t$ - value of 2.756 and significance level of 0.007 (significant at 5\% level). Therefore, market power has significant positive effect on the profitability of banks. This result is different from hypothesis $\mathrm{HO}_{2}$ stating that market power has no significant effect on the profitability of banks in Nigeria. Relatively, the result is similar with the finding of Tregenna ${ }^{[21]}$ (2009) that observed market power has increasing influence on the profitability of banks in USA.

Moreover, exchange rate has positive regression coefficient $\beta$ value of 0.040 with standard error of 0.043 , $t$-value of 0.943 and significance level of 0.348 . Therefore, exchange rate has insignificant positive effect on the profitability of banks. This result is different from hypothesis $\mathrm{HO}_{3}$ stating that exchange rate has no significant effect on the profitability of banks in Nigeria. This result is similar with the finding of Antonina ${ }^{[20]}$ (2011) that observed insignificant positive effect of exchange rate on the profitability of banks in Ukraine. But, the result is different from the findings of Khrawish et al. ${ }^{[18]}$ (2011) that identified significant negative effect of exchange rate on the profitability (ROA) of Islamic banks in Jordan.

However, credit risk has insignificant negative $\beta$ value of -1.101 with standard error of $0.062, \mathrm{t}$ - value of -1.624 and significance level of 0.108 . So, credit risk has no significant negative effect on banks profitability (ROA). This result is similar with hypothesis $\mathrm{HO}_{2}$ stating that credit risk has no significant effect on the profitability of banks in Nigeria. Yuqi ${ }^{[2]}$ (2008) and Antonina ${ }^{[20]}$ (2011) observed significant negative effect of credit risk on the profitability of banks in Ukraine while Buyinza ${ }^{[23]}(2010)$ observed significant positive effect of credit risk on the profitability of banks in SSA Countries.

On diagnose test of the model one (1), the values of $R, R^{2}$ and adjusted $R^{2}$ are $0.316,0.100$ and 0.069 respectively. The value of $\mathrm{R}^{2}$ is the coefficient of correlation that explains the relationship between the dependent and independent variables (which is a weak positive relationship). On the other hand, the value of adjusted $\mathrm{R}^{2}$ explains that 6.9 percent of the variation in the dependent variable (ROA) is explained by the 
independent variables of the model. The value of $\mathrm{F}$ statistic is 3.184 with significance level of 0.028 (significant at $10 \%$ level). Therefore, the model is not fit for this study going by $\mathrm{F}$ statistic rule of fitness, because if $\mathrm{F}$ statistic is significant at one (1) percent (0.000-0.005), the model is considered to be fit (Srairi, 2009). But, the value of Durbin Watson (DW) is 1.893 which is an evidence of relative serial correlation. If the value of DW is less than one (1) as rough rule of thumb, there may be cause for alarm (Khrawish et al. $\left.{ }^{[18]}, 2011\right)$. This means there are dual standards of measuring the model fitness. Looking at the model fitness, the model one is fit for this study going by DW standard of measurement.

Thus, we accept the hypotheses $\mathrm{HO}_{1}$ and $\mathrm{HO}_{3}$ stating that credit risk and exchange rate have no significant effects on the profitability of banks in Nigeria. But, we reject hypothesis $\mathrm{HO}_{2}$ stating that market power has no significant effect on the profitability of banks in Nigeria.

TABLE 3.2: Summary of Regression Result (Model two)

\begin{tabular}{|c|c|c|c|c|}
\hline \multirow{2}{*}{ Model 2} & Coefficients & \multirow[b]{2}{*}{ Standard Error } & \multirow[b]{2}{*}{$\mathbf{t}$} & \multirow{2}{*}{ Significance Leve } \\
\hline & $\beta$ & & & \\
\hline Constant $(\alpha)$ & $69.696 * *$ & 25.264 & 2.759 & 0.007 \\
\hline Credit Risk & -0.289 & 0.290 & -0.996 & 0.322 \\
\hline Market Power & $0.098 *$ & 0.053 & 1.854 & 0.067 \\
\hline Exchange Rate & $-0.355^{*}$ & 0.201 & 1.767 & 0.081 \\
\hline $\mathrm{R}$ & 0.337 & & & \\
\hline $\mathrm{R}^{2}$ & 0.114 & & & \\
\hline Adjusted $\mathrm{R}^{2}$ & 0.083 & & & \\
\hline F Statistics & $3.684 *$ & & & \\
\hline Significance of $F$ & $\rightarrow$ & $\rightarrow$ & $\rightarrow$ & 0.015 \\
\hline Durbin Watson & 2.012 & & & \\
\hline
\end{tabular}

Dependent variable: Return on Equity (Profitability).

Significance Level: One percent (***), Five percent $(* *)$, Ten percent $(*)$

Source: Author Computation using SPSS, 2013.

TABLE 2.2 indicates the values of estimated linear regression coefficients of bank size, market power and exchange rate with constant $\beta$ value of 69.696. Market power has significant positive coefficient $\beta$ value of 0.098 with standard error of $0.053, \mathrm{t}$ - value of 1.854 and significance level of 0.067 (significant at $10 \%$ level). Therefore, market power has the highest significant positive effect on profitability (ROE) of banks. This result is different from hypothesis $\mathrm{HO}_{2}$ stating that market power has no significant effect on the profitability of banks in Nigeria. The result is similar with the finding of Tregenna ${ }^{[21]}$ (2009) that observed market power has increasing influence on the profitability of banks in USA.

Exchange rate has negative regression coefficient $\beta$ value of -4.000 with standard error of $0.179, \mathrm{t}$ value of -2.240 and significance level of 0.028 (significant at $10 \%$ level). Therefore, exchange rate has significant negative effect on the profitability of DMBs. This result is different from hypothesis $\mathrm{HO}_{3}$ stating that exchange rate has no significant effect on the profitability of banks in Nigeria. Khrawish et al. ${ }^{[18]}$ (2011) identified significant positive effect of exchange rate on the profitability (ROE) of Islamic banks in Jordan.

Credit risk has insignificant negative $\beta$ value of -0.289 with standard error of $0.290, t-$ value of -0.996 and significance level of 0.322 . Thus, credit risk has no significant negative effect on banks profitability (ROE). This result is also similar with hypothesis $\mathrm{HO}_{2}$ stating that credit risk has no significant effect on the profitability of banks in Nigeria. Yuqi ${ }^{[2]}(2008)$ and Antonina ${ }^{[20]}$ (2011) observed significant negative effect of credit risk on the profitability of banks in Ukraine while Buyinza ${ }^{[23]}$ (2010) observed significant positive effect of credit risk on the profitability of banks in SSA Countries.

On diagnose test of the model, the values of $\mathrm{R}, \mathrm{R}^{2}$ and adjusted $\mathrm{R}^{2}$ are $0.337,0.114$ and 0.083 respectively. The value of $\mathrm{R}^{2}$ is the coefficient of correlation that explains the relationship between the dependent and independent variables (which is a weak positive relationship). On the other hand, the value of adjusted $\mathrm{R}^{2}$ explains that 8.3 percent of the variation in the dependent variable (ROE) is explained by the independent variables of the model. The value of $\mathrm{F}$ statistic is 3.684 with significance level of 0.015 (significant at $10 \%$ level). Therefore, the model is fit for this study going by $\mathrm{F}$ statistic rule of fitness, because if $\mathrm{F}$ statistic is significant at 1 percent $(0.000-0.005)$, the model is considered to be fit (Srairi $\left.{ }^{[7]}, 2009\right)$. However, the value of Durbin Watson (DW) is 2.012 which is an evidence of relative serial correlation. If the value of DW is less than one (1) as rough rule of thumb, there may be cause for alarm (Khrawish et al. $\left.{ }^{[18]}, 2011\right)$. This means there are dual standards of measuring the model fitness. Looking at the model fitness, the model two is fit for this study going by DW standard of measurement.

From the analysis, we accept the hull hypothesis $\mathrm{HO}_{1}$ stating that credit risk has no significant effect on the profitability of banks in Nigeria. But, we reject the hull hypotheses $\mathrm{HO}_{2}$ and $\mathrm{HO}_{3}$ stating that credit risk and exchange rate have no significant effects on the profitability of banks in Nigeria. 


\section{1. $\quad$ Results and Discussion}

The summary of Pearson Correlation Coefficients and regression results obtained from data analyses are show in TABLE 4.1 below

TABLE 3.1 Summaries of Pearson Correlation and Regression Results

\begin{tabular}{|c|c|c|c|c|c|c|c|}
\hline \multirow{2}{*}{$\mathbf{S} / \mathbf{N}$} & \multirow{2}{*}{$\begin{array}{c}\text { Independent } \\
\text { Variable }\end{array}$} & \multirow{2}{*}{$\begin{array}{c}\text { Dependent } \\
\text { Variable }\end{array}$} & \multicolumn{2}{|c|}{ Correlation } & \multicolumn{2}{|c|}{ Regression } & \multirow{2}{*}{$\begin{array}{r}\begin{array}{r}\text { Decision } \\
\text { Criteria }\end{array} \\
\text { Accept or } \\
\text { Reject }\left(\mathbf{H}_{0}\right.\end{array}$} \\
\hline & & & $\begin{array}{c}\text { Coefficient } \\
\text { Value }\end{array}$ & $\begin{array}{c}\text { Significance } \\
\text { Level }\end{array}$ & $\begin{array}{c}\text { Coefficient } \\
\text { Value }\end{array}$ & $\begin{array}{c}\text { Significance } \\
\text { Level }\end{array}$ & \\
\hline \multirow[t]{2}{*}{$\mathrm{i}$} & \multirow[t]{2}{*}{ Credit Risk } & $\begin{array}{c}\text { Profitability } \\
\text { (ROA) }\end{array}$ & -0.116 & 0.278 & -0.101 & 0.108 & Accept \\
\hline & & $\begin{array}{c}\text { Profitability } \\
\text { (ROE) }\end{array}$ & $-0.208^{*}$ & 0.049 & -0.289 & 0.322 & Accept \\
\hline \multirow[t]{2}{*}{ ii } & \multirow[t]{2}{*}{ Market Power } & $\begin{array}{c}\text { Profitability } \\
\text { (ROA) }\end{array}$ & $0.269^{* *}$ & 0.010 & $0.031^{* *}$ & 0.007 & Reject \\
\hline & & $\begin{array}{l}\text { Profitability } \\
\text { (ROE) }\end{array}$ & $0.180 *$ & 0.089 & $0.098 *$ & 0.067 & Reject \\
\hline \multirow[t]{2}{*}{ iii } & \multirow[t]{2}{*}{ Exchange Rate } & $\begin{array}{c}\text { Profitability } \\
\text { (ROA) }\end{array}$ & 0.015 & 0.891 & 0.040 & 0.348 & Accept \\
\hline & & $\begin{array}{c}\text { Profitability } \\
\text { (ROE) }\end{array}$ & $-0.267^{*}$ & 0.011 & $-0.355^{*}$ & 0.081 & Reject \\
\hline
\end{tabular}

Significance Level: One percent (***), Five percent $(* *)$, Ten percent $(*)$.

Tail Test: Two (2)

Source: Author Computation using SPSS, 2013.

The TABLE 3.1 shows summary of correlation and regression results as follow below:

i. Observing the profitability (ROA), the correlation result tells us that credit risk has insignificant negative relationship with profitability. The regression result also tells us that credit risk has no significant negative effect on profitability. We therefore, accept the hull hypothesis because the result is similar with hypothesis $\mathrm{HO}_{1}$ stating that credit risk has no significant effect on the profitability of banks in Nigeria. Though, in the profitability (ROE), the correlation result tells us that credit risk has significant negative relationship with profitability. The regression result tells us that credit risk has no significant negative effect on profitability. We therefore, accept the hull hypothesis because the result is similar with hypothesis $\mathrm{HO}_{1}$ stating that credit risk has no significant effect on the profitability of banks in Nigeria. That means credit risk will insignificantly decline with the profitability. The insignificant decline in credit risk has negative effect on banks in Nigeria.

ii. A glance at the profitability (ROA), the correlation result reveals that market power has significant positive relationship with profitability. The regression result also reveals that market power has significant positive effect on profitability. So, we reject the hull hypothesis because the result is different from hypothesis $\mathrm{HO}_{2}$ stating that market power has no significant effect on the profitability of banks in Nigeria. Also in the profitability (ROE), the correlation result reveals that market power has significant positive relationship with profitability. The regression result reveals that market power has significant positive effect on profitability. So, we reject the hull hypothesis because the result is different from hypothesis $\mathrm{HO}_{2}$ stating that market power has no significant effect on the profitability of banks in Nigeria. That means market power will significantly rise with the profitability of banks. The significant rise in market power has positive effect on the profitability of banks in Nigeria.

iii. Looking at the profitability (ROA), the correlation result explains that exchange rate has insignificant positive relationship with profitability. The regression result also affirms that exchange rate has insignificant positive effect on profitability. Thus, we accept the hull hypothesis because the result is the same with hypothesis $\mathrm{HO}_{3}$ stating that exchange rate has no significant effect on the profitability of banks in Nigeria. This means exchange rate will insignificantly rise with the profitability (ROA) of banks. The insignificant rise in exchange rate has positive effect on the profitability of banks in Nigeria. However, in the profitability (ROE), the correlation result explains that exchange rate has significant negative relationship with profitability. The regression result explains that exchange rate has significant negative effect on profitability. Thus, we reject the hull hypothesis because the result is different from hypothesis $\mathrm{HO}_{3}$ stating that exchange rate has no significant effect on the profitability of banks in Nigeria. This means exchange rate will significantly decline with the profitability (ROE) of banks. The significant decline in exchange rate has negative effect on the profitability of banks in Nigeria.

From the above summary analysis, we accept the hypotheses $\mathrm{HO}_{1}$ and $\mathrm{HO}_{3}$ stating that credit risk and exchange rate have no significant effects on the profitability (ROA \& ROE) of banks in Nigeria. We may also reject the hypothesis $\mathrm{HO}_{3}$ stating that exchange rate has no significant effect on the profitability (ROE) of banks in Nigeria. In addition, we reject the hypothesis $\mathrm{HO}_{2}$ stating that market power has no significant effect on the profitability (ROA \& ROE) of banks in Nigeria. 


\section{Conclusion and Recommendations}

Profit oriented objective is main reason why banking business come to existence. This profit is measured by either Return on assets (ROA) or Return on Equity (ROE). Banks operations and activities are focusing on profit making objective. Managements have to formulate policies on determinants that have effect on the profitability of banks. The policies are on credit risk, market power and exchange rate which are bank specific and industrial/macroeconomic determinants. Thus, this research study recommends that managements should continue to:

i. ensure that they continue to maintain low level of credit risk in order to increase the profitability. This is because the insignificant decline in credit risk has negative effect on the profitability of banks.

ii. increase and maintain their market share known as market power. The reason is that, the significant rise in market power has positive relationship with the profitability of banks and

iii. adequately anticipate exchange rates fluctuations they transact on, despite exchange rate has significant negative effect on profitability of banks measured by ROE. This is because stable exchange rates add value to the profitability of banks in Nigeria.

\section{References}

[1] Karwai, S.A. (2006). Assessment of the Efficacy of the Failure Resolution Options in the Nigerian Banking Industry. Journal of Business Administration, Ahmadu Bello University, Zaria, Vol.1, No.2, pp: 27-36.

[2] Yuqi, L. (2008). Determinants of Banks' Profitability and its Implication on Risk Management Practices: panel Evidence from the UK in the period 1999 - 2006. Unpublished Dissertation, University of Nottingham, UK. Retrieved June 22, 2011, from edissertation. nottingham.ac.uk/137.

[3] Sanusi, L.S. (2010). Global Financial Meltdown and the Reforms in Nigeria. Being the Public Lecture Delivered by CBN, Governor at Convocation Square, Abubakar Tafawa Balewa University, Bauchi. Retrieved August 18, 2011, form www.cenbank.org/out/speeches/2010/g...

[4] Egwurube, O.A. (2010). Reform of Banking Sector and Issue of Economic Development in Nigeria:A lesson from Sub-Saharan Africa Countries. International Journal of Business and Management Tomorrow.Vol,2, No.3, PP:1-12, Retrieved December 22, 2012, from www.ijbmt.com.

[5] Soludo, C.C. (2004). Consolidating the Nigeria Banking Industry to Meet the Developmental Challenges of the 21 Century. Being an Address Delivered to the Special Meeting of the Bankers' Committee Held on July 6, at the CBN Headquarters, Abuja. Retrieved August 06, 2011, from www.cenbank.org/out/speeches/2004/govadde-6jul.pdf

[6] Sufian, F. (2011). Profitability of the Korean Banking Sector: Panel Evidence on Bank Specific Specific and Macroeconomic Determinants. Journal of Economics and Management, Vol. 7, No.1, pp: 43 - 72. Retrieved July, 10, 2011, from www.jem.or.tw/../03.pdf

[7] Srairi, S.A. (2009). Factors Influencing the Profitability of Conventional and Islamic Commercial Banks in GCC Countries. Journal of Islamic Economics, Vol.13, No.1, pp: 5-30. Retrieved August 6, 2011, from iaie.net/.../DImage.aspx?.../...

[8] Ramlall, I. (2009). Bank specific, Industrial Specific and Macroeconomic Determinants of Profitability in Taiwanese' Banking System: Under Panel Data Estimation, International Research Journals of Finance and Economics, ISSN 160-167,issue 34.Retrieved August 03,2011, from http://www.eurojournals.com/finance.htm.

[9] Flamini, V.; Mc Donald, C. and Schumacher, L. (2009). The Determinants of Commercial Bank Profitability in Sub- Saharan Africa. IMF Working Paper (WP/09/15). Retrieved June 17, 2011, from www.imf.org/../wp0915.pdf.

[10] Jhingan,M.L. (2001). International Economics, $5^{\text {th }}$ revised edition, Vrinda Publications (P) LTD, Delhi- India. pp.367.

[11] Solomon, J. (2007). Essentials of Economics, fourth edition, Pearson Education Limited, England, pp.237

[12] Pandey, I.M. (2010). Financial Management, Tenth Edition, Vikas Publishing House PVT LTD, New Delhi, India, pp.5,179, 594$597 \& 807$.

[13] Somoye, R..O.C. (2008). The Performance of Commercial Banks in Post Consolidation Period in Nigeria: An Empirical Review. European Journal of Economics and Administrative Sciences, Issue 14, PP: 63-73. Retrieved August 14, 2011, from http//www.eurojournals.com

[14] Saidu, R.M. and Tumin, M.H. (2011). Performance and Financial Ratios of Commercial Banks in Malaysia and China. International Review of Business Research Paper, Vol.7, No.2, pp: 157 - 169. Retrieved July 5, 2011, from www.Bizresearch papers.Com/11.Rasid...

[15] GUL, S.; Irshad, K. and Zaman,K. (2011). Factors Affecting Bank Profitability in Pakistan. The Romanian Economics Journal, Vol. XIV, No.39, pp: 61-87, March-2011. Retrieved June 24, 2011, from www.rejournal.eu/portals/o/Achiva/G...

[16] Ali, K.; Akhtar, M.F. and Ahmed, H.Z. (2011). Bank specific and Macroeconomic Indicators of Profitability- Empirical Evidence from the Commercial Banks of Pakistan. International Journal of Business and social sciences, Vol. 2, No.6, pp: 237-241, April. Retrieved July12, 2011, from joc.hcc.edu.pk/../24.pdf

[17] King Fahd University (2010). Profitability of Islamic Banks in the GCC Region. Department of Finance Finance and Economics, College of Industrial, King Fahd University of Petroleum and Minerals, Dhahran, Saudi Arabia. Retrieved July 20, 2011, from www.wbicopro.com/615-Houcem.pdf.

[18] Khrawish ${ }_{1}$, H.A; Siam, W.Z. and Khrawish 2 , A.H. (2011). Determinants of Islamic Banks Profitability: Evidence from Jordan. Middle Eastern Finance and Economics Journal, Issue 13, pp: 42 - 57. Retrieved July 12, 2011, from eurojournals.com/MEFE-1304-pdf.

[19] Coffinet, J.; Lin, S. and Matins, C. (2010) Stress Testing Banks Profitability: Evidence from France. French Bank Commission. Retrieved July 06, 2011, from gdre-mbf-2010.u.bordeaux4.fr/sites...

[20] Antonina, D. (2011). Determinants of Bank Profitability in Ukraine. Undergraduate Economic Review Journal, Vol.7, issue: Article 2. Retrieved June 06,2011,from http:// digital commons.iwu.edu /uer/vol7/iss1/2.

[21] Tregenna, F. (2009). The Fat Years: The Structure and Profitability of the US Banking Sector on the Pre-crises Period. Oxford Journal of Economics, Vol.33, issue 4, pp: 609 - 632. Retrieved June 03, 2011, from cje.Oxford journal.org/../609.Full.

[22] Graham, C. and Bordeleau, E.(2010). The Impact of Liquidity on Bank Profitability. Bank Canada Working Papers. Retrieved August 10, 2011, from www.banque-france .Fr/fondation/ fr/t... 
[23] Buyinza, F. (2010). Determinants of Profitability of Commercial Banks in Sub-Sahara Africa Countries. Unpublished Work of the Department of Economics, Johanassen Keppler University, Linz - Austria. Retrieved June 24, 2011, from www.econ.jku.at/... buyinza. pdf.

[24] Sabo, B. (2007). An Assessment of the Determinants of the Nigeria Banking Industry Profitabilty. Using Panel Evidence from Nigeria Commercial Banks. Information Manager Journal, Vol.7, No. 2, pp : 14 - 20. Retrieved August 20, 2011, from www.ajol.info/../27197.

[25] Ani, W. U., Ugwunta, D. O., Ezeudu, I. J. and Ugwuanyi, G. O. (2012). An empirical assessment of the determinants of bank profitability in Nigeria: Bank characteristics panel evidence. Journal of Accounting and Taxation, Vol. 4. No 3, pp. 38-43, December, 2012. Retrieved November 7, 2013, from http://academicjournals.org/article/article1379422336_Ani\%20et\%20al.pdf

[26] Bosede, A. F.; Olusegun, O. and Olubukunola, U. (2013). Return on investment of DMBs in Nigeria. Journal of Applied Finance \& Banking, Vol. 3, No. 3, May, 2013, 195-206. Retrieved October 6, 2013, from http://www.scienpress.com/Upload/JAFB/Vol\%203_3_14.pdf

[27] John and Oke (2013) John E. E. and Oke M.O.(2013). Capital Adequacy Standards, Basle Accord and Bank Performance: The Nigerian Experience (A Case Study of Selected Banks in Nigeria). Asian Economic and Financial Review Journal, Vol.3, No2, pp: 146-159. Retrieved November 3, 2013, from www.aessweb.com/download.php?id=1767

[28] Aremu, A.M.; Ekpo, I. C. and Mustapha A. M. (2013). Determinants of Bank Profitability in a Developing Economy: Evidence from Nigeria Banking Industry. Interdisciplinary Journal of Contemporary Research in Business, Vol. 4 No 9, pp: 155-181, January-2013. Retrieved November 3, 2013, from http://journal-archieves27.webs.com/155-181.pdf

[29] Soyemi, K.A.; Akinpelu, L. and Ogunleye, J.O. (2013). The Determinant of Profitability Among DMBs in Nigeria Post Consolidation. Global Advanced Research Journal of Economics, Accounting and Finance, Vol. 2. No.5, pp. 93-103, August, 2013. Retrieved October 30, 2013, from http://garj.org/garjeaf/pdf/2013/August/Soyemi\%20et\%20al.pdf

[30] Aminu, B.A. (2013). The Determinants of Bank's Profitability in Nigeria. Thesis submitted to the Institute of Graduate Studies and Research in Partial fulfillment of the Requirements for the Degree of Master of Science in Banking and Finance Eastern Mediterranean University, January- 2013 Gazimağusa, North Cyprus. Retrieved November 7, 2013, fromhttp://irep.emu.edu.tr:8080/jspui/bitstream/11129/641/1/Aminu.pdf

[31] CBN (2011), List of Financial Institutions (Deposit Money Banks). Retrieved on April 24, 2012, from www.cenbank.org/Supervision/Inst - DM.asp

[32] NSE (2011). Nigeria Stock Exchange. Daily Trust Newspaper of Friday, December 30, pp.25

\title{
Appendix
}

List of Quoted and Unquoted Deposit Money Banks (DMBS) in Nigeria Stock Exchange (NSE) as at 30th December, 2012

\author{
Quoted Banks in Nigeria Stock Exchange \\ 1. Access Bank PLC (Acquired Intercontinental Bank PLC) \\ 2. Diamond Bank PLC \\ 3. Ecobank Nigeria PLC (Acquired Oceanic Bank PLC) \\ 4. First City Manument Bank PLC \\ 5. Fidelity Bank PLC \\ 6. First Bank of Nigeria plc \\ 7. Guaranty Trust Bank PLC \\ 8. Stanbic IBTC Bank PLC \\ 9. Skye Bank PLC \\ 10. Sterling Bank PLC \\ 11. United Bank of Africa PLC \\ 12. Union Bank of Nigeria PLC \\ 13. Unity Bank of Nigeria PLC \\ 14. Wema Bank PLC \\ 15. Zenith Bank PLC
}

\section{Unquoted Banks in Nigeria}

1. Citibank Nigeria Limited

2. Enterprise Bank Limited (Formerly Spring Bank PLC)

3. Finbank PLC (Formerly First Inland Bank PLC)

4. Keystone Bank Limited (Formerly Bank PHB PLC)

5. Mainstreet Bank Limited (Formerly Afribank Nigeria PLC)

6. Standard Charted Bank Nigeria Limited

Source: $\left(\mathrm{CBN}^{[31]}, 2011 \& \mathrm{NSE}^{[32]}, 2011\right)$. 